\title{
IAMJ
}

INTERNATIONAL

AYURVEDIC

MEDICAL JOURNAL

\section{A REVIEW ON THE ROLE OF VIRECHANA IN VARIOUS SKIN DISEASES}

\author{
Kanchan Thakur ${ }^{1}$, Suneel Pal Singh ${ }^{2}$ \\ Assistant professor in department of Panchkarma, Dev Bhoomi Medical College of Ayurveda \& Hospital, \\ D. Dun, Uttarakhand, India \\ Associate professor in department of Panchkarma, Shivalik Institute of Ayurveda, Uttarakhand, India
}

Corresponding Author: dr.kanchanthakur01@gmail.com

https://doi.org/10.46607/iamj3009112021

(Published Online: November 2021)

Open Access

(C) International Ayurvedic Medical Journal, India

Article Received: 25/10//2021 - Peer Reviewed: 05/11/2021 - Accepted for Publication: 06/11/2021

\section{Check for updates}

\begin{abstract}
Virechan is one of the Shodhan Chikitsa described in ayurvedic texts. It is mainly advised in the pitta and rakta Pradhan diseases. All skin diseases in ayurveda have been considered under kustha. At present time antibiotics and antifungal medicines are being resistant, so it is becoming difficult day by day to cure such skin diseases, but in Ayurveda, Virechan karma is a very powerful therapy to combat these diseases. Skin is the index of our body. Healthy skin represents a healthy body. Improper usage of foods and drinks along with unhealthy activities manifest diseases. Virechan karma is the second therapy in the sequence of panchakarmas, the most widely used purificatory procedure especially for paitika and raktas diseases. It is also useful in the disorders in which pitta is associated with vata or kapha. Ayurveda states that sluggish liver (dysfunction of the liver) associated with doshic imbalance causes skin diseases. There are so many skin diseases that are not curable by other procedures. According to Ayurveda Virechan karma is very much beneficial in curing the different obstinate skin diseases as psoriasis, eczema, acne vulgaris, vitiligo, leukoderma etc. Ayurveda always looks to the root cause so the patient can restore their body to a healthy state and eliminate the symptoms of skin diseases. This article deals with various skin diseases and their treatment by using Virechan therapy.
\end{abstract}

Keywords: Virechan, Shodhanchikitsa, Skin Diseases, Psoriasis, Panchkarma, 


\section{INTRODUCTION}

The removal of Dosha through the 'Adhobhaga' is symbolized as Virechana. It is one of the Shodhana Karma as mentioned in the Ayurvedic texts. Regarding this definition, commentator Chakrapani has clarified 'Adhobhaga' means 'Guda' (Anal passage). By this route, the Dosha can be eliminated by Niruha Basti also, but Niruha Basti has no power of 'Adhobhaga harana' and so Niruha Basti cannot be included under Virechana karma ${ }^{1}$. Virechana is a supreme procedure out of all Panchkarma, especially for the elimination of Pittadosha ${ }^{2}$. Virechan is a very effective therapy for skin diseases. As before said that in the treatment of pitta dosha Virechan is beneficial because the skin is the place where Bhrajak pitta is situated, and good skin is the result of balanced Bhrajak pitta. Acharya Sushruta was the first person to describe Bhrajak Pitta as a variety of Pitta. He has also used the term Bhrajaka for Bhrajja Pitta. According to Acharya Chakrapani commenting on the above states that the regulation of body heat $\&$ complexion variation is the function of Bhrajaka Pit$t a^{3}$. Shodhana therapy is the most important measure for Bahudosha Vyadhi. If Doshas are depleted with Shamana therapy, there are chances to provoke that Doshas again, but if they are removed by Shodhana therapy, there are no chances to provoke again ${ }^{4}$. Skin diseases are almost described under the topic Kushta and Kushta is tridosajvyadhi, it is the reason that shodhan karma is best in skin diseases. Virechana cleanses sense organs i.e., improves their function, purifies body tissues, increases digestive power of Agni i.e., Jatharagni, Dhatvagni etc., proper applied Virechana karma acts a key role in the delaying age factors. In Malbhoota Ashayas (weakened organ) Dosha Dushya Samucchaya persists. This Samuccha$y a$ is eradicated only through means of Virechana (Shodhana). Shamana Chikitsa fails in this matter. As a result, it cannot treat any disease radically ${ }^{5}$.

\section{Skin-}

In modern the skin is classified into two main parts: first is superficial, thinner portion, which is composed of epithelial tissue, is Epidermis and second is deeper, thicker connective tissue portion is Dermis.
The Epidermis is avascular, and the Dermis is vascular, that's why, by cutting the layer of the epidermis is not bleed, but if we cut the dermis it bleeds. Deep to the dermis, but not part of the skin, is the subcutaneous layer, known as the Hypodermis. This layer consists of areolar and adipose tissues ${ }^{6}$.The Epidermis is further grouped into five layers ${ }^{7}$ :

1. Stratum Corneum or Horny Layer

2. Stratum Lucidum

3. Stratum Granulosum

4. Stratum Spinosum or Malphigian Layer

5. Stratum Basale or Germinative Layer the Dermis is further divided into two regions ${ }^{8}$ :

I. Papillary region

II. Reticular region

According to Ayurveda Aacharya Sushruta the concept of Twacha in Shareera Sthana (Sushrutashareera Shrestha) as Twacha has seven layers, Avabhasini is the first layer of skin that provides colour to the skin. It is Adhishthana of Sidhma (small ulcers) and Padmakantaka (Pemphigus mollaceous), The second layer is lohita It is Adhishthana of Tilkalaka (moles), nyachchha (pimples) and vyanga (acne vulgaris). Shveta is the third layer in which Charamdala, Ajagalli and Mashaka (taenia infection of skin and candidiasis) skin diseases are occurring. The fourth layer of Twacha is Tamra, it is the place of different Kilasa (lepromatous)and Kustha (tuberculoid leprosy). Vedini is the fifth layer of skin, Kushtha (leprosy) and Visarpa (erysipelas) occur in this layer. Rohini is the sixth layer of Twacha, it is Adhishthana of Granthi (varicose veins), Apachi (benign tumours), Arbuda (tumours), Shlipada (filariasis) and Galaganda (goitre) disease. The seventh or last layer of skin is Mamsadhara, it is the site of Bhagandara (fistula-in-ano), Vidradhi (abscess) and Arsha (piles) disease ${ }^{9}$.

\section{Classification of Virechana ${ }^{10}$ :}

Virechana has no classification however Acharya Sharangadhara has classified it as follows -

Anulomana: The drug which forwards the Mala after their digestion and breaking their Bandha are known as Anulomana e.g., Haritaki. Here, bandha means 
bandha of Vayu. Acharya Sushruta has given synonyms of Anulomana as Sara, and acharya Dalhana adds that Anulomana causes expulsion of Vata and Kapha. Acharya Bhavamishra has considered undigested doshas as Mala rupa and said that drugs that expel them are anulomana. From a practical viewpoint, the meaning 'removal of bandana of Vayu' fits more appropriately to Anulomana karma.

Sramana: The drug which expels half-digested and sticky Mala without its prior digestion is known as Sramana, e.g., Aragavadha. Bhavaprakasha opines that 'Adi' of word Maladi denotes Kapha and Pitta, hence the field of Sramsana widens. The difference between Anulomana and Sramsana is the absence of digestion of Mala in Sramsana indicating it's a bit stronger property.

Bhedana: The drug which disintegrates the Abaddha (unformed) or Baddha (well-formed) or Pindita (dried faecal mass) Pindita mala and directs it outside the body through the lower gut is known as Bhedana. E.g., Katuki. Here, the drug potency is more, and it can expel even the hard, Pindita stool.

Rechana: The drug, which eliminates digested as well as undigested Mala or Dosha by making them watery through the anal route are known as Rechana e.g. Trivrit. Here Adhamalla's adds that this class of drugs not only eliminates the digested or indigested Mala in watery form, but it also does this very quickly (reheats). The word Rechana sounds like Virechana, but the latter lacks the Purva karma and Pashchat karma, having only localized effects.

Indication of Virechana- Kushtha (Skin diseases), Visphotaka (Eruptions), Pandu, Indigestion ${ }^{11}$, visarpa, vatarakta ${ }^{12}$, Hyper pigmentation, Leukoderma, Psoriasis, Dermatitis, Herpes zoster ${ }^{13}$,

\section{Role of virechana karma in skin diseases}

Virechana is very much beneficial in curing different obstinate skin diseases. A comparative single-blind critical trial in 20 patients suffering from ekakushtha (psoriasis) has shown that virechana karma is very effective in the remission of the illness. Patients were initially subjected pachana chikitsa with oral administration of jeerakadi churna in a dose of 5 grams tid. This was followed by abhyantra snehpana with gug- gulu tiktaka ghrita till the attainment of symptoms of proper snehana. Following abhyanga and svedana the patients were treated with virechana karma by oral administration of trivritlehya in a dose of 30 to 40 grams. After the virechana and samsarjana kar$m a$, the patients were treated with shaman chikitsa with arogyavardhini rasa in a dose of $500 \mathrm{mg}$ tid along with aragvadhadi kashaya. The study revealed the best improvement and complete remission of the illness in the majority of the patients as assessed by the psoriasis severity index score. The results were also statistically highly significant ${ }^{14}$. A research article said about psoriasis that Virechana karma is commonly supported in the management of psoriasis as it helps in correcting the basic pathogenic factors with pitta, rakta, Agni, twak. $50 \%$ relief in symptoms after the shodhana therapy. Thus, Virechana karma (purgation therapy) followed by internal medications is considered the best line of management for skin disorders ${ }^{15}$. Eczema is characterized by itching, dryness of skin, swelling, reddening, dryness, and flaking. Scratching of skin results in rashes. In Ayurveda, this disease is known as Vicharchika. Eczema is triggered when the immunity of the body is affected - the trigger may be caused due to various reasons like irritants (soap, shampoos, detergents, disinfectants), allergens (pets, pollen, dust mites), bacteria, hot and humid temperature, perspiration, food items (stale, spicy, fermented, fried food items), stress, excessive intake of items like tea, coffee, alcohol and many others ${ }^{16}$. Virechan therapy by its detoxification process shows a good impact on eczema ${ }^{17}$. A research revealed that oral administration of GuduchiBhringaraja Rasayanaand Shrishadi decoction and Shujyadi Lepa local application after Virechana Karma increased cure rate nearly $80 \%$ in patients of Vicharchika significantly. Also, $91.7 \%$ of no recurrence rate was reported. Treatment was given for 60 days and each Dosha's improved remarkably ${ }^{18}$. Vitiligo is a common, developed, discolouration of the skin, characterized by well-circumscribed, ivory, or chalky white macules which are flush to the skin surface $^{19}$. In the treatment of vitiligo or leukoderma shodhan (Virechan) therapy is useful. According to 
this article, the crable kustha do not recur if pathological factors are expelled out by Shodhana ${ }^{20}$. Acne Vulgaris is a chronic inflammatory condition of the pilosebaceous units, characterized by the formation of comedones, erythematic papules and pustules, less frequently nodules or cysts too ${ }^{21}$.Virechana is a method, which is much safer, less complicated in acne vulgaris or muchdushika ${ }^{22}$. Virechana karma does the cleansing the Kostha and brings down the vitiated Dosha from the body and helps to maintain the Dosha and Dhatu Samya or keep up the homeostasis and leads to the restoration and reconstruction of body tissues and also boost the body immunity and cleanses of the Srotas (microchannels). Therefore, virechana is a very important therapeutic measure for skin disease ${ }^{23}$.Virechana drugs having the properties like Ushna, tikshna, Sukshma, Vyavayi and Vikasi ${ }^{24}$ due to these properties' medicines reach the Hrudaya and circulate through the vessel. Due to the Ushna property present in medicine, they liquify the doshas located in the entire body, thus doshas move towards GIT, morbid doshas reaches the stomach carried by Udana vayu, due to the predominance of prithvi and Jala Mahabhuta in virechana dravya, it starts the downward movement of doshas from Koshta and leads to the expulsion of unwanted toxin from the body ${ }^{25}$.

\section{CONCLUSION}

Virechana is a better treatment or therapy for curative aspects as well as preventive aspects in skin diseases. Virechana Therapy is recommended and is highly beneficial for the Detoxification in case of accumulation of Pitta dosha like skin disorders, blisters, abscess, liver disorders etc. as skin diseases occurs mainly because of pitta dosha or rakta dosha thus Virechan is useful in it. Among all types of Shodhanakarma Virechana karma is agra (superior). It is beneficial for improving blood circulation while nourishing the skin, improving digestion, strengthening muscles, and eliminating stress.

\section{REFERENCES}

1. Acharyasidhinandan Mishra, Charak Samhita, the second part, chaukhambha orientaliya, Varanasi, first edition-2009, reprint-2012, page no-852.

2. Acharyasidhinandan Mishra, Charaksamhita, the first part, chaukhambha Orientaliya, Varanasi, first edition2009, reprint-2016, page no- 300.

3. Acharyasidhinandan Mishra, Charaksamhita, the first part, chaukhambha orientaliya, Varanasi, first edition2009, reprint-2016, page no-194

4. Acharyasidhinandan Mishra, Charak Samhita, the first part, chaukhambha Orientaliya, Varanasi, first edition2009, reprint-2016, page no-250

5. Acharyapriyavratasharma, sushruta Samhita, part 1, chaukhambaorientalaia, Varanasi, reprint-2014, page no-515.

6. Anatomy and Physiology 2015 Indian Edition by Gerard J. Tortora and Bryan Derrickson. Wiley India Pvt Ltd., 4435 36/7, Ansari Road, Daryaganj, New Delhi- 110002. Reprint: 2016; 125

7. . Anatomy and Physiology 2015 Indian Edition by Gerard J. Tortora and Bryan Derrickson. Wiley India Pvt Ltd., 4435 36/7, Ansari Road, Daryaganj, New Delhi- 110002. Reprint: 2016; 128-129.

8. Anatomy and Physiology 2015 Indian Edition by Gerard J. Tortora and Bryan Derrickson. Wiley India Pvt Ltd., 4435 36/7, Ansari Road, Daryaganj, New Delhi- 110002. Reprint: 2016; 130.

9. Sushruta Samhita, Ayurveda tatva Sandeepikahindi commentary Author: Kaviraj Ambikadatta Shastri published by Chowkhamba Sanskrit Sansthan Varanasi reprint edition Sushruta Samhita Shareerasthanach. 2010; 4(4)

10. Dr. bhramanandtripathi, sharagdharsamhita, dipikatika, chaukhambhasurbhartiprakashan, Varanasi, edition- 2020, page no-33-35

11. Dr Vasant. C Patil, Principles and Practices of Panchkarma, Reprint -2017, Page number- 372

12. Raghuramayyagari, Panchkarma practical manual, 2nd edition 2021, 2nd edition 2021

13. Dr Vasant C. Patil, Essentials of Practical Panchkarma Therapy, Reprint -2019, Page number- 250

14. Ref- Dr G. Shrinivasa Acharya, Panchkarma illustrated the first edition -2006 , reprint $-2009,2013 \mathrm{pg}$. no. 339

15. Dr Bikash Raj Ghimire, Chief Consultant \& Medical Director, Kashyap Ayurveda, Kathmandu, Nepal. ROLE OF VIRECHANA KARMA (THERAPEUTIC 
PURGATION) IN PSORIASIS - A CASE STUDY WORLD JOURNAL OF PHARMACEUTICAL AND MEDICAL RESEARCH, wjpmr, ISSN 2455-3301

16. http://www.ayurvedakendra.in/skin-problems/

17. Pallavi Hegde, D T Hemanth, S V Emmi, M P Shilpa, Pradeep S Shindhe, Y M SantoshInt J Ayurveda Res. 2010 Oct-Dec; 1(4): 268-270. DOI: 10.4103/09747788.76792 PMCID: PMC3059451

18. Role of Rasayana in cure and prevention of recurrence of vicharchika (eczema). Kaur M1, Chandola HM. http://www.ncbi.nlm.nih.gov/pubmed/2213168242

19. Sehgal VN. Vitiligo. Textbook of clinical dermatology.4th edition. Jaypee: New Delhi; 2004.p. 99-101

20. Pretya Juyal, VIRECHANA IN VITILIGO: A RAY OF HOPE, International journal of advanced research (ijar), ISSN: 2320-5407

21. Nicholas A. Boon, NickiR.Colledge Brian R. Walker International Editor John A.A. Hunter. Davidson's Principle \& Practice of Medicine, 20th Edition 2006,
Chapter 27 Skin Disease, Acne \& Rosacea, Page No.1299-1300.

22. Lalita Sharma, Alok Srivastava, Parul Sharma, \&K.K. Sharma. (2019). EFFICACY OF VIRECHANA KARMA IN THE MANAGEMENT OF ACNE VULGARIS. International Journal of Ayurveda and Pharma Research, 7(7), 78-81. Retrieved from https://ijapr.in/index.php/ijapr/article/view/1258

23. shushruta; shushrutasamhita, with nibandhasangrahatika by dalhanacharya, published by chaukambha orientalia 7th edition, 2009; 442.

24. Acharyasidhinandan Mishra, Charak Samhita, the second part, chaukhambha orientaliya, Varanasi, first edition- 2009, reprint-2012, page no-852.

25. PretyaJuyal, VIRECHANA IN VITILIGO: A RAY OF HOPE, International journal of advanced research (ijar), ISSN: 2320-5407

\section{Source of Support: Nil \\ Conflict of Interest: None Declared}

How to cite this URL: Kanchan Thakur \& Suneel Pal Singh: A Review On The Role Of Virechana In Various Skin Diseases. International Ayurvedic Medical Journal \{online\} 2021 \{cited November 2021\} Available from: http://www.iamj.in/posts/images/upload/2835 2839.pdf 